\title{
The Transactional Leadership Styles to Organizational Commitment and Islamic Performance of Sharia Bank in South Sulawesi
}

\author{
Muchran BL \\ Universitas Muhammadiyah Makassar, Indonesia \\ muchranmuchriana@gmail.com
}

\begin{abstract}
This study aims to examine and analyze the effect of transactional leadership to organizational commitment and Islamic performance of Sharia Bank in South Sulawesi. Leader is one of the most important elements that will never disappear from human social life. It arises because of the differences in people's lives are heterogeneous, which then need to put together diselerasikan and directed to the differences that do not result in conflict. There are several types of leadership among transactional leadership. This study was conducted in South Sulawesi with focus on: 1) Sharia BTN, 2) Sharia Mandiri, 3) Sharia BNI, 4) Sharia Muamalah; 5) Sharia BRI, 6) Sharia Niaga; 7) Sharia Mega; 8) Sharia Bukopin; 9) Sharia Sulselbar and 11) Sharia Permata. The main tool in this study is a questionnaire submitted to the Islamic Bank employees in the province of South Sulawesi were selected as sample. It is necessary for item analysis with Structural Equation Modeling (SEM). The results showed that the transactional leadership is significantly influence the Islamic performance. Next, the transactional leadership has no significant effect on the Islamic performance through the organizational commitment.
\end{abstract}

Keywords: Islamic Performance, Leadership Style, Transactional Leadership Styles, Organizational Commitment, Sharia Bank

\section{Introduction}

Building the foundation of an effort to implement Islamic economic theory really lies in the condition of the human factor as the culprit. In this regard, it is undeniable that the employee's performance will be a primary gauge of any success achieved by a business organization, including the Islamic Banking business. In an effort to improve the performance of employees at the Islamic way Islamic banks are, of course, will be greatly influenced by the motivation and organizational commitment. Then, various views and efforts have been implemented to improve the performance of employees in Islamic banks, but in essence very believed that everything will not be separated and must be preceded by consistent efforts to establish Islamic leadership style as well. One form of economic system based on the law (sharia) Islam is the emergence of Islamic banking. This effort is based on the establishment of a ban on the Islamic religion to collect and borrow with interest or usury as well as the so-called ban on investment for businesses categorized as unlawful. It is not guaranteed by the conventional banking system, in addition to the Islamic banks Islamic economic mission in the fight against ignorance, poverty, kedhaliman, evil, and injustice to reach Falah. The rapid growth of Islamic banking can not be separated from the contribution of human resources who manage it. Individual contribution to the organization will be higher if the organization can give you the desires of the individual. Each individual member of the organization have personal goals that are often different both with the purpose of individual members of other organizations, as well as different from the goals of the organization. To adjust the objectives (goals congruence) will require a leader who coordinates and directs the objectives and goals of the organization members to be harmonious. Leadership context then becomes a subject the first is seen as an important part of the big picture concept of Islamic banking organizations.

There are several types of leadership among transactional leadership. Transactional leadership is developed based on the theory of Maslow's needs consisting of five hierarchical needs ranging from physical to selfactualization needs. Level lower subordinate needs such as physical needs, security and affiliates can be met by the transactional leadership style. Other forms of transactional leadership is a leader-member exchange theory to explain the process of making the role of a leader with a subordinate. The rationale for this theory is that the leaders are usually set a very good exchange relationship with a subordinate person who believes in 
("in group") that serves as an assistant or adviser. Exchange relationship built with the rest of the subordinate ("ouf group) substantially. Exchange relations formed on the basis of personal suitability and competence and reliable capabilities of subordinates. Dyadic exchange followed a series of developments which differ for each subordinate. In the low exchange relationships are mutually affect the level is relatively low. Basic to create a high exchange relationship is the leader control over desired outcomes subordinates. These results include, among others: the provision of interesting and exciting task, delegation of responsibility and authority of the larger, more sharing of information, the increase in salaries, special allowances and support as well as personal approval, ease of subordinate career. As a reward for status, influence and greater allowance, a subordinate who has a high exchange has the obligation and the extra cost. Subordinates are expected to work harder, have a greater commitment to the objectives of duty, loyalty to the leader, and share administrative responsibility sebagain leaders. The third stage in accordance with transformational leadership, while in the first stage according to transactional leadership. Interesting to study about the study of transactional leadership style influence on the performance of employees through organizational commitment Islami and Islami performance of employees in Islamic banks in the province of South Sulawesi.

\section{Theoretical Framework}

Leadership: Leadership according to Robbins (2000: 93) is the ability to influence people in a group toward the achievement of certain goals. Basically an organization's leadership has three elements, namely: 1 . The purpose that drives the human being, 2. The presence of a group of people, 3 . The leader directs and give effect to human, system and mechanism 4 . The existence of leadership, vision and 5 . There mission .

Leadership Styles: Empirical is the meaning of leadership activities performed by humans in the life of a community in an effort to realize the unity (sociality), can thus be identified as follows: (Nawawi, 1993: 20)

- In leadership always faced two sides called the first party and the other party leaders are those who lead. Number of leaders certainly less than the led. Leadership is a social phenomenon, which takes place as an interaction between people in the group, either in the form of a large group that involves many people, as well as a small group with a number of people involved in it a little.

- Leadership as activities concerning lead containing lead, guide, guides show you the way, heads and train so that people can work on their own headed. Furthermore, it also explained that the leadership in Islam is a leadership practice the moral values of Islam to manage an organization, such as the nature of the trust (trustworthy), is (justice), shura "(consultation) and others (Tasmara, 1995: 46). The leadership paradigm in Islam consists of two parts: (Tasmara, 1995: 48)

a. Formalistic legal paradigm, namely the leadership exercised by the Muslims, the principles that are used also Islam, symbols are used also reflect Islam. This is regardless of whether the way in the lead was adhered to the basic principles when Islamic or not.

b. Substantial essential paradigm, namely leadership in which there are values of Islam practiced in managing subuah organizations, such as keeping the nature of trust, honesty, fairness, consensus, sincerity, responsibility, and so forth. This is done regardless of whether the people involved in it Muslims or nonMuslims. In the Islamic view of leadership is trust and responsibility are not only accountable to the members they lead but also be accountable before God Almighty.

Teori Path goal: Results of research on leadership to explain how leadership behaviors affect the satisfaction and performance of subordinate dependent on aspects of the situation and characteristics of the subordinate task characteristics. According to Davis (2000) defined four leadership behaviors are: Supportive Leadership, Leadership Directive, Participative Leadership, and Leadership Achievement.

Theory $\mathrm{X}$ and $\mathrm{Y}$ : Theory $\mathrm{X}$ is emphasizing the role of the company's leadership in providing the motivation appears as the destination, and of how tolerant of workers by providing the satisfaction of needs through the realization of organizational goals together, then the leaders should compromise the techniques work so that all parties agree with organizational goals and objectives of the workers, leaders should also create situations 
that help meet the needs of individuals as well as development. Thus it can be explained that the theory $\mathrm{X}$ and $Y$ give impetus to find the best way of managing human resources. From the study of the conventional theory and empirical studies, it was found indicators of leadership variables are as follows: (Dessler, 1996: 45)

- Task-oriented behavior means that a leader must be task-oriented job.

- Relationship-oriented behavior, meaning that a leader must provide support and help subordinates.

- Supportive Leadership, Leadership Directive, Participative Leadership, Leadership Achievement.

- Responsibility means that a leader must be responsible in carrying out job duties,

- A leader must be able to provide encouragement and influencing and directing subordinates to achieve goals.

- Having a purpose and a clear orientation where the direction of the organization he leads

- Tolerance means having an attitude is not rigid (formalistic) for employees, and so forth.

While the Islamic studies, found some indicators of leadership variables are as follows: (Nawawi, 2001: 61)

- The ability to realize the will of Allah through His Messenger.

- Leading, guiding, guide, show the way, heads and train the people they lead.

- Amanah is responsible for justice

- Shura 'means deliberation.

- Being able to be a role model.

- Able to carry out the regeneration of its members or others as a substitute after he was no longer leading.

- honest in word, deed and behavior

- Tabligh means to convey everything that needs to be delivered correctly / openness, and so forth.

Transactional Leadership: Level lower subordinate needs such as physical needs, security and affiliates can be met by the transactional leadership style. Other forms of transactional leadership are a leader-member exchange theory to explain the process of making the role of the leader with a subordinate. The rationale for this theory is that the leaders are usually set a very good exchange relationship with a subordinate person who believes in ("in group") that serves as an assistant or adviser. Exchange relationship built with subordinates. Exchange relations formed on the basis of personal suitability and competence and reliable capabilities of subordinates. Dyadic exchange followed a series of developments which differ for each subordinate. In the low exchange relationships are mutually affect the level is relatively low. Basic to create a high exchange relationship is the leader control over desired outcomes subordinates. These results include, among others: the provision of interesting and exciting task, delegation of responsibility and authority of the larger, more sharing of information, the increase in salaries, special allowances and support as well as personal approval, ease of subordinate career. As a reward for status, influence and greater allowance, A subordinate who has a high exchange has the obligation and the extra cost. Subordinates are expected to work harder, have a greater commitment to the objectives of duty, loyalty to the leader, and share administrative responsibility as leaders.

Work Motivation: According to Schein (1999: 70), "motivation is a set that can cause individuals perform certain activities and to achieve certain goals anyway". In line with the thinking Schein and Gallerman in Robbins (1996: 92) explains that "motivation is unsatisfied needs that encourage individuals to achieve certain goals". As for anything related to human needs, Mc Clelland (1961: 81) argues that there are three kinds of human needs, namely:

- Needs For Achievement, namely the need for achievement is a reflection of the impulse responsibility for solving the problem.

- Needs For Affiliation, namely the need for affiliation which is an encouragement to interact with others, being with others, do not want to do anything harmful to others.

- Needs For Power, namely the need for power is a reflection of its drive to achieve authority in choosing an influence on others.

Motivation is often interpreted as an encouragement that is in a person to do anything in order to achieve certain goals in order to meet the needs of both physical and psychological. In order to meet the psychological 
needs of Allah has given special characteristics in every creature according to its functions. Among the special characteristics of the most important in the creation of human nature is the physiological motivation. Motivation is an important side of human life that accommodates physical needs, fulfill or replace any shortages, and straightening shock or imbalance (Darmawan, 2006: 23).

Islamic Motivation: Spiritual motivation of a Muslim is composed in three parts, namely the motivation of monotheism or faith means that the motivation that comes from within due to the strength of faith, the motivation of worship, which means motivation born of governance divine rule governing the relationship ritual directly between slave with his Maker and motivation Muamalat, which means motivation appears as the divine governance rules that govern the relationship between human beings and other creatures.

Organizational Commitment: A growing phenomenon in the world of industry professionals and organizations are likely to be more committed to the profession than the company where she worked. Employees who are committed to the profession do not necessarily refer to an organization, so that employees like this are always moving work to another (Fineman et al., 2005). The phenomenon is one of them caused by the gap between employees working in one company with employees working in other places, although they have the same job description. Some people are affected in ahkirnya take a decision to move the work to another company, but not a few who decided to keep working in related companies. Rashid et al. (2003: 277) states that organizational commitment is a psychological condition that characterizes the relationship between employees and the organization. The implication is that the persistence of an employee of a member organization. The commitment can be defined as a social actor willingness to provide energy and loyalty to the social system as an effective complement to the organization, regardless of the relationship that is truly worth. Organizational commitment built through a process of identifying where a person does something of an idea as the development of himself. Commitment is a belief in, acceptance of, the goals and values of the organization and the profession. Commitment is also a willingness to give a great effort for the organization and the desire to remain a member of the organization.

Organizational Commitment Islamic: Islamic organizational commitment indicators can be structured as follows:

- Work is ţā'atullāh (obedience to God)

- Work sincere as worship

- I'timād 'ala nafsih (independence of the work)

- istiqamah (consistent) in work

Performance Islamic employee: In the Islamic view of assessing the performance of a religious person can be seen from several indicators. (Zadjuli, 1999), among others, the intention of the operation is due to Allah, in working to apply the rules / norms / Shari'ah kaffah, spiritual motivation is to seek their fortune in the world and in the hereafter, applying the principles of efficiency and benefits while maintaining the survival, maintain a balance between the search for treasure with worship, grateful to God by not consumptive, issued ZIS, and sympathize orphans and the poor. As a consequence and for imperfect humans as creatures of God, the man is required to work with the best (in earnest). Performance religious (Islamic) always involve religious science and technology so that the quality of work is not the same with the usual performance, because humans are commanded to be able to master science and technology in order to become a man of Achievement and useful for the benefit of all mankind on earth (rahmatan lil- alamin).

Figure 1: Model Research

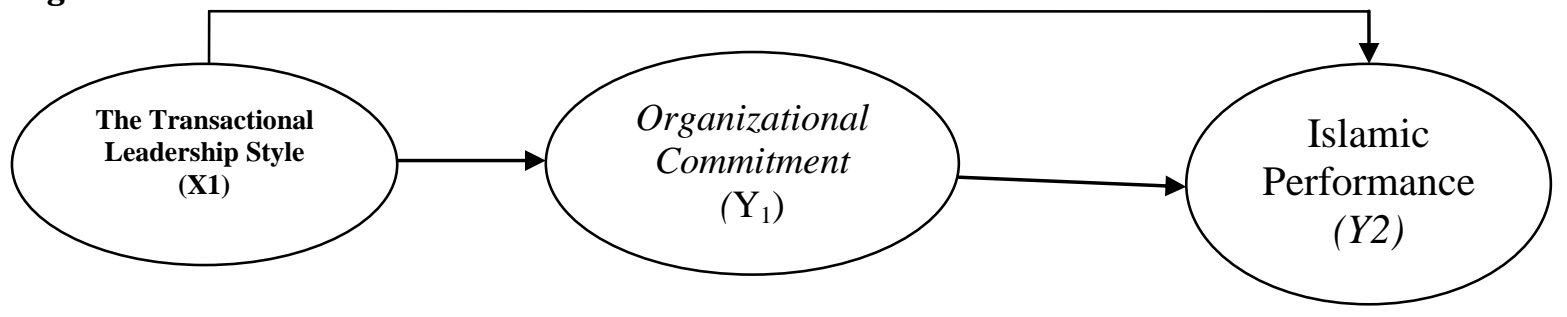


Hypothesis Development: Shape function can explicitly restated in the form of a linear function to be estimated by linear regression simultaneously, as follows:

$\mathrm{Y} 2=\mathrm{a}+\mathrm{a} 1+\mathrm{a} 2 \mathrm{Y} 1 \mathrm{X} 1+\mathrm{e}$

Where:

Y1 = Organizational commitment

$\mathrm{Y} 2$ = Islamic Performance

$\mathrm{X} 1=$ The Transactional Leadership Styles

$\mathrm{a}=$ Constants

$\mathrm{a} 1, \mathrm{a} 2$, , parameters to be estimated with the hypothesis of a relationship directional sign ( + or).

$\mathrm{e}=$ Error

Based on the formulation of research objectives and the conceptual framework, it can be arranged hypothesis is as follows:

H1: Transactional leadership style is positive and significant impact on organizational commitment to the Islamic Bank of South Sulawesi.

H2: Transactional leadership and significant positive effect on the performance of employees at Bank Syariah Islami in South Sulawesi

H3: Organizational commitment and significant positive effect on the performance of employees at Bank Syariah Islami in South Sulawesi.

\section{Results}

Data Analysis Basically, this study qualitatively constructed with reference to the deductive way of thinking, so that this research ultimately uses a quantitative approach (mainstream). Therefore, the study variables are latent variables that need to be measured quantitatively by converting qualitative data (perception) into a numeric scale (Likert scale, 1-5). Then, this study refers to the hypothesis to be tested through a variety of statistical techniques. Type hypothesis being tested is hypothesized relationship (associative) which is built from existing theoretical framework (deductive). Thus, this study also includes explanatory research (Singarimbun, 1995: 4). This study was designed to survey method with a sample of 10 employees at the bank. The survey was conducted with questionnaires and interviews to obtain descriptions and depict a fact, the classification and measurement of data distribution patterns and relationships between a number of sociological and psychological variables (Sugiyono, 2001: 63). The survey data is then processed for analysis based on the conceptual framework of this research to finally taken a generalization according to the level of accuracy of a representative sample. And the final results of this study does not rely on the ability of software statistical analysis such as Analysis Of Moment Structure (Amos) and Linear Sructural Relationship (lisrel) used to subsequently determine the choice of the best model by manipulating the birthday field data, but the results of this study should still be consistent according to what is (initial estimate results without the need to modify the data) to guide the conceptual framework that has been designed and preset.

Table 1: Coefficient of Estimated Direct and Indirect Effect Either Variable to Variable Endogen Exogenous and the Islamic Employee Performance (Y2)

\begin{tabular}{lllll}
\hline $\begin{array}{l}\text { Hypoth } \\
\text { esis }\end{array}$ & $\begin{array}{l}\text { Influence the direction } \\
\text { between variables }\end{array}$ & $\begin{array}{l}\text { coefficient } \\
\text { Line }\end{array}$ & t-Statistic & Probability \\
\hline 1 & $X_{1}=>Y_{1}$ & $0,908^{*}$ & 2,802 & 0,005 \\
2 & $X_{1}=>Y_{a}$ & $1,521^{*}$ & 2,004 & 0.045 \\
3 & $Y_{1}=>Y_{2}$ & 0,657 & 1,623 & 0,105 \\
\hline
\end{tabular}

Note: ${ }^{*}$ ) Significant at $\alpha=5 \%$

Discussion: Based on the analysis by using Structural Equation Modeling are shown in the table above, the results of hypothesis testing can be described as follows:

- The direct effect of transactional leadership style (X2) on organizational commitment (Y2) showed a positive and significant influence with $t$ value of 2.802 ( $t$-statistic $>2$ with a significant 5 percent) and the coefficient of 0.908 . This means that the better transactional 
leadership of the leaders, the better the organizational commitment of employees. Conversely, the worse the transactional leadership style of a leader, the organizational commitment of employees would be decreased. These results are not in accordance with the initial hypothesis which states that there is a negative relationship between transactional leadership and organizational commitment.

- The direct effect of transactional leadership (X2) on the performance of employees Islami (Y3) showed a positive and significant influence with $t$ value of 2.004 (t-statistic $>2$ with a significant 5 percent) and the coefficient of 1.521. This means that the better the transactional leadership style of a leader, it will be better the performance of Islamic employees. Conversely, the worse a transactional leadership style of leadership, the worse the performance of the Islamic employees. These results are consistent with the initial hypothesis which states that there is a positive relationship between transactional leadership and performance Islami employees.

- The direct effect of Organizational Commitment (Y2) of the Islamic Performance Employees (Y3) showed no significant effect with $t$ value of 1.623 (t-statistic $<2$ with a significance of 5 percent) and the coefficient of 0.657. This means that the merits of an employee organizational commitment, it will not affect the performance of employees Islami. These results are not in accordance with the initial hypothesis stating the existence of a positive relationship between organizational commitment to employee performance Islami.

\section{Conclusion and Recommendations}

The transactional leadership style to the organizational commitment showed a positive and significant influence. This means that the better transactional leadership of the leaders, the better the organizational commitment of employees. Conversely, the worse the transactional leadership style of a leader, the organizational commitment of employees at the Islamic Bank of South Sulawesi would be decreased. Transactional leadership style on the performance of employees Islamic showed positive and significant impact. This means that the better the transactional leadership style of a leader, it will be better the performance of Islamic employees. Conversely, the worse a transactional leadership style of leadership, the worse the performance of the employees at Bank Syariah Islami in South Sulawesi. Organizational Commitment to Employees Islami performance showed no significant effect. This means that the merits of an employee organizational commitment, it will not affect the performance of employees at Bank Syariah Islami in South Sulawesi. Based on the results, discussion and conclusions of this study, the following was conveyed some suggestions as inputs for the Islamic banking Islamic banking especially in South Sulawesi. For the employees, so that employees better understand the Islamic values of a different conventional and Islamic banking. So the sharia-based banking in practice is really based on Islamic ordinance is good and right. A good understanding of Islamic values is not expected to be created in the Islamic banking system but in ourselves and everyday employees. For the leaders, so that in addition to being an exemplary also has the ability, knowledge of the Islamic leadership that has been taught by the Messenger of Allah SWT. Also increases the associated expertise in Islamic approaches to increase the commitment, organization and performance of employees in Islamic banks in South Sulawesi

\section{References}

Darmawan, C. (2006). Kiat sukses Manajemen Rosulullah:Manajemen Sumber daya Insani berbasis nilai-nilai Ilahiah, Jakarta : Khasanah Intelektual.

Davis, K. (2000). Perilaku Dalam Organisasi, Jilid I, Edisi Ketujuh, Erlangga, Jakarta

Dessler, G. (1996). Manajemen Sumber Daya Manusia, Edisi 7, Alih Bahasa : Benyamin Molan, Jakarta : Prenhanlindo

Fineman, S., Sims, D. \& Gabriel, Y. (2005). Organizing and Organizations 3rd Ed. British: Sage Publication, Ltd.

Mc. Clelland, D. C. (1961). The Achieving Society. New York: D. Van Nostrand Company, Inc.

Nawawi, H. (1993). Manajemen Sumber Daya Manusia untuk Bisnis Yang Kompetitif, Yogyakarta : Penerbit Gadjah Mada University Press.

Nawawi, H. (2001). Metode Penelitian Bidang Sosial. Gajah Mada University. Press.Yogyakarta 
Rashid, M. Z. A., Sambasivan, M. \& Rahman, A. A. (2003). The Influence of Organizational Culture on Attitudes toward Organizational Change. Leadership and Organizational Development Journal, 1(2).

Robbins, S. (1996). Perilaku Organisasi. Jakarta: PT Raja Grafindo

Robbins, S. (2000). Perilaku Organisasi, Jilid 1, Alih bahasa: Hadyana Pujaatmaja, Jakarta : Prenhallindo.

Schein, E. H. (1999). Organizational Culture and Leadership, 2nd Ed. San Fransisco, Jossey - Bass Publishers

Singarimbun, M. (1995). Metode Penelititan Survei. LP3S, Jakarta

Sugiyono. (2001). Metode Penelitian Administrasi, Penerbit Alfabeta Bandung

Tasmara, T. (1995). Etos Kerja Pribadi Muslim, Jakarta : Penerbit PT. Dana bhakti Wakaf.

Zadjuli, S. I. (1999a). Prinsip-Prinsip Ekonomi Islam, Surabaya: Fakultas Ekonomi Universitas Airlangga. 